Available online at https://ojs.unud.ac.id/index.php/bse/index

Vol. 27 No. 1, Februari 2022, pages: 64-78

ISSN : $1410-4628$

e-ISSN: $\underline{2580-5312}$

\title{
CORPORATE GOVERNANCE DALAM KEPUTUSAN HEDGING PADA MASA SEBELUM DAN SELAMA PANDEMI COVID-19
}

\author{
Andy Yesaya Tjandra ${ }^{1}$ Andry Irwanto ${ }^{2}$
}

Article history:

Submitted:

15 Januari 2022

Revised:

3 Februari 2022

Accepted:

3 Februari 2022

\section{Keywords:}

Corporate Governance;

Hedging Decisions;

Profitability;

Leverage.

\section{Kata Kunci:}

Corporate Governance;

Keputusan Hedging;

Profitabilitas;

Leverage.

\section{Koresponding:}

Universitas Airlangga, Jawa

Timur, Indonesia

Email:

andytjandra81@gmail.com

\section{Abstract}

This study was conducted to determine the effect of corporate governance mechanisms with profitability and leverage as variable control on hedging decisions in manufacturing companies listed on the Indonesia Stock Exchange for period 2019-2020. This research was conducted using a quantitative approach with logistic regression research methods. The sample in this study amounted to 183 companies. The results of this study indicate that board of commissioners has positive and significant, independent commissioner has positive and not significant, institutional ownership has negative and not significant, managerial ownership has negative and not significant, family duality has negative and not significant influence before and during the pandemic Covid-19 and there are no differences in corporate governance mechanisms that have the most significant influence on hedging decisions before and during pandemic Covid-19.

\section{Abstrak}

Penelitian ini dilakukan untuk mengetahui pengaruh mekanisme corporate governance dengan variabel kontrol profitabilitas dan leverage terhadap keputusan hedging pada perusahaan manufaktur yang terdaftar pada Bursa Efek Indonesia periode tahun 2019-2020. Penelitian ini dilakukan dengan menggunakan pendekatan kuantitatif dengan metode penelitian regresi logistik. Sampel dalam penelitian ini berjumlah 183 perusahaaan. Hasil penelitian ini menunjukkan dewan komisaris berpengaruh positif signifikan, komisaris independen berpengaruh positif tidak signifikan, kepemilikan institusional berpengaruh negatif tidak signifikan, kepemilikan manajerial berpengaruh negatif tidak signifikan, dan family duality berpengaruh negatif tidak signifikan terhadap keputusan hedging pada masa sebelum dan selama pandemi Covid-19 serta tidak terdapat perbedaaan mekanisme corporate governance yang paling berpengaruh signifikan terhadap keputusan hedging sebelum dan selama pandemi Covid-19.

Universitas Airlangga, Jawa Timur, Indonesia $^{2}$

Email: ongkiandryl@gmail.com 


\section{PENDAHULUAN}

Corona Virus Disease 2019 pertama kali masuk Indoensia terdeteksi sejak 02 Maret 2020 dan WHO menetapkan sebagai pandemi sejak 11 Maret 2020 (WHO, 2020). Hal ini menyebabkan ekonomi Indonesia mulai menurun dan mengalami resesi di triwulan III tahun 2020 dimana pertumbuhan ekonomi nasional Indonesia minus selama 2 triwulan berurutan (Kementerian PPN/Bappenas, 2020).

Pertumbuhan ekonomi Indonesia didukung oleh transaksi perdagangan internasional yaitu transaksi ekspor dan impor. Berdasarkan jumlah transaksi yang dilakukan, transaksi ekspor dan impor di Indonesia dapat dirincikan menurut jenis mata uangnya. Dari data statistik Bank Indonesia, transaksi ekspor dan impor di Indonesia didominasi oleh transaksi dengan menggunakan mata uang US Dollar.

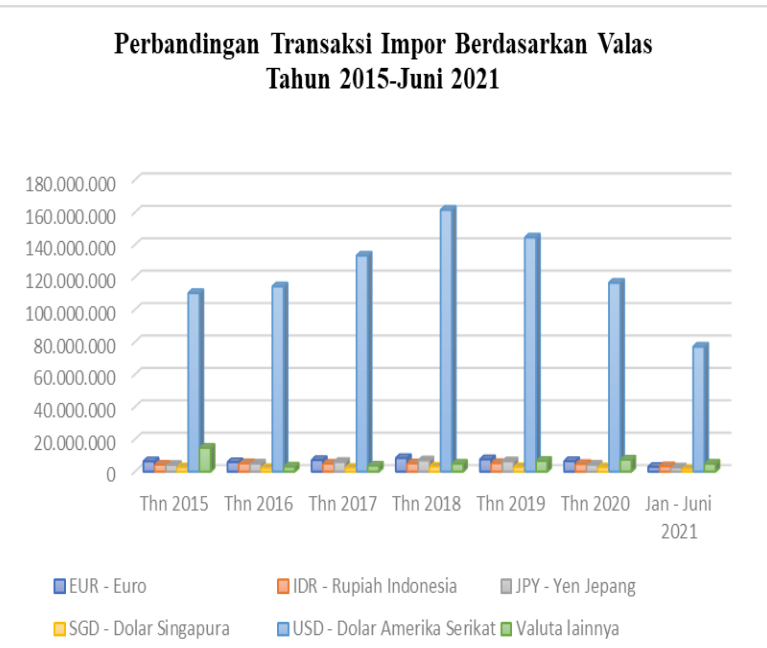

Sumber: data statistik BI yang diolah, 2021

Gambar 1.

Grafik Perbandingan Transaksi Impor
Perbandingan Transaksi Ekspor Berdasarkan Valas Tahun 2015-Juni 2021

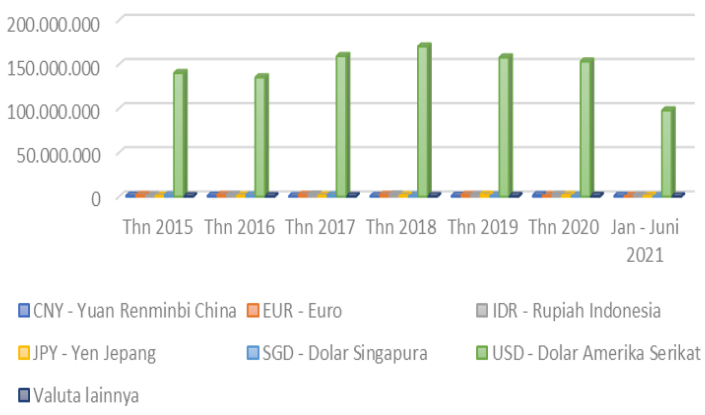

Sumber: data statistik BI yang diolah, 2021

Gambar 2.

Grafik Perbandingan Transaksi Ekspor

Fluktuasi kurs IDR terhadap US Dollar menyulitkan perusahaan dalam melakukan transaksi dalam US Dollar. Oleh karena itu, penelitian ini berfokus pada mata uang US Dollar. Kondisi pandemi Covid-19 ini mengakibatkan pergerakan nilai valuta IDR terhadap valuta asing khususnya US Dollar berfluktuasi tinggi.

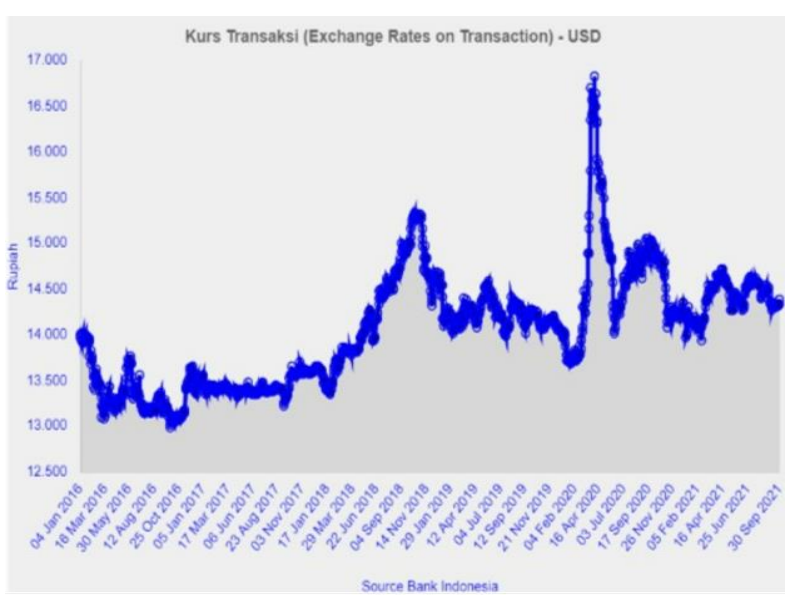

Sumber: www.bi.go.id, 2021

Gambar 3.

Pergerakan Kurs Tengah BI pada Januari 2016September 2021 
Hal ini dapat menyulitkan perusahaan yang terikat kontrak transaksi mata uang asing karena akan menghadapi risiko eksposur transaksi valuta asing yang timbul dan mengalami kesulitan dalam memproyeksikan arus kas di masa mendatang.

Perusahaan perlu mengatasi risiko fluktuasi mata uang US Dollar dengan menerapkan manajemen risiko melalui aktivitas hedging pada kontrak transaksi. Aktivitas hedging dapat dilaksanakan melalui penggunaan instrumen derivatif berupa kesepakatan jual/beli mata uang asing dengan nilai kurs saat ini dimana pembayarannya dilakukan kemudian hari pada waktu yang disepakati.

Faktor eksternal yang mempengaruhi keputusan hedging adalah tingkat suku bunga dan nilai tukar. Sedangkan kondisi kesulitan keuangan, rasio nilai pasar terhadap nilai buku, leverage, liquidity, dan growth opportunity menjadi faktor internal yang mempengaruhi pengambilan keputusan hedging.

Manajemen risiko melalui hedging merupakan unsur penting dalam terwujudnya prinsip corporate governance yang baik di perusahaan. Pelaksanaan corporate governance yang baik dapat meningkatkan performa perusahaan. Good corporate governance merupakan suatu tatanan pengaturan dan pengendalian perusahaan yang memberikan value added untuk para pemangku kepentingannya (Kaihatu, 2006).

Usaha peningkatan penerapan good corporate governance oleh Bapepam-LK. Lembaga ini sebagai regulator dalam pasar modal memiliki kewajiban untuk mengupayakan penerapan corporate governance yang baik pada perusahaan publik dan emiten dengan menerbitkan peraturan dan kebijakan terkait good corporate governance di Indonesia yang bertujuan untuk melindungi hak para pemangku kepentingan dengan diimbangi kewajiban mereka.

Penelitian Lel pada perusahaan non finansial di Bursa Efek pada 30 negara periode tahun 1990-1999 menyatakan corporate governance memiliki dampak penting dalam pengambilan keputusan hedging (Lel, 2012). Hal ini sejalan dengan penelitian Muiru pada 54 perusahaan pada NSE (Nairubi Securities Exchange) pada periode tahun 2011-2016 dimana hasil penelitiannya menyatakan yang pertama corporate governance dapat memoderasi hubungan antara hedging dan kinerja keuangan dan yang kedua CEO Duality dan Ownership Structure dapat memperkuat atau melemahkan efektivitas teknik hedging (Muiru et al., 2019).

Penelitian Kyere \& Ausloos yang dilakukan pada 252 perusahaan non keuangan di London Stock Exchange periode tahun 2014 menyatakan board size berpengaruh signifikan terhadap peningkatan performa keuangan yang diukur dari ROA dan Tobin's $\mathrm{Q}$, board independence dapat mempengaruhi kinerja keuangan. Insider shareholdings, CEO Duality, dan frekuensi rapat audit komite tidak mempengaruhi kinerja keuangan (Kyere \& Ausloos, 2021).

Penelitian Bhagawan \& Lukose yang dilakukan pada 332 perusahaan non keuangan di National Stock Exchange of India periode tahun 2009 menyebutkan adanya hubungan 
positif signifikan antara faktor leverage dengan keputusan hedging dan terdapat hubungan negatif signifikan antara ROA dengan keputusan hedging (Bhagawan \& Lukose, 2017). Sedangkan penelitian Aslikan \& Rokhmi yang dilakukan pada perusahaan manufaktur di Bursa Efek Indonesia periode tahun 2010-2015 menyatakan leverage berpengaruh negatif signifikan terhadap keputusan hedging dan growth opportunity berpengaruh positif signifikan terhadap keputusan hedging serta financial distress berpengaruh positif signifikan terhadap keputusan hedging (Aslikan \& Rokhmi, 2017).

Adanya keterkaitan antara keputusan hedging dan corporate governance menjadi alasan bahwa pengambilan keputusan hedging perlu diperhatikan, khususnya di masa pandemi Covid-19. Pengambilan keputusan hedging memerlukan penerapan corporate governance untuk melindungi kepentingan para pihak dan meningkatkan nilai perusahaan. Oleh sebab itu, tujuan penelitian ini menganalisa pengaruh corporate governance dalam pengambilan keputusan hedging pada perusahaan publik sektor manufaktur dengan menggunakan lima mekanisme corporate governance yaitu Dewan Komisaris, Komisaris Independen, kepemilikan institusional, kepemilikan manajerial, dan family duality dengan variabel kontrol profitabilitas dan leverage yang dilakukan pada periode tahun 20192020. Penelitian ini juga menganalisa adakah perbedaan mekanisme corporate governance yang paling berpengaruh signifikan terhadap keputusan hedging antara sebelum pandemi
Covid-19 yaitu tahun 2019 dan selama pademi Covid-19 yaitu tahun 2020.

Penelitian ini menggunakan sampel Perusahaan publik manufaktur karena memiliki permasalahan dan kondisi yang lebih kompleks dan luas serta terdiri dari berbagai macam sub sektor industri sehingga diharapkan dapat memberikan gambaran dan informasi mengenai perusahaan di Indonesia. Selain itu perusahaan manufaktur juga melakukan aktivitas pengadaan bahan baku untuk produksi dan penjualan barang jadi yang dapat melibatkan transaksi mata uang asing.

Corporate governance merupakan suatu tatanan pengelolaan bisnis atau kegiatan usaha korporasi yang terstruktur sehingga terjadi peningkatan nilai-nilai perusahaan dan kontinuitas usaha (Kusmayadi et al., 2015). Perusahaan perlu menerapkan good corporate governance yang mana dapat mengatasi konflik antara agen dengan prinsipal dan memberikan dampak positif untuk performa perusahaan (Kyere \& Ausloos, 2021).

Menurut UU PT No 40 tahun 2007, Dewan Komisaris bertugas mengawasi dan memberikan arahan kepada Direksi dalam pengambilan keputusan kegiatan operasinal perusahaan. Menurut Komite Nasional Kebijakan Governance tahun 2006, Komisaris Independen adalah seseorang yang sama sekali tidak memiliki hubungan kekeluargaan ataupun bisnis dengan pemegang saham pengendali. Jumlah Komisaris independen harus dapat menjamin agar mekanisme pengawasan berjalan secara efektif dan sesuai dengan peraturan perundang-udangan. Ketentuan BAPEPAM No: KEP-315/BEJ/06-2000 yang 
Corporate Governance Dalam Keputusan... Andy Yesaya Tjandra \& Andry Irwanto

disempurnakan dengan surat keputusan No. KEP-339/BEJ/07-2001 di Indonesia, untuk mencegah kerugian pemegang saham minoritas maka BAPEPAM mensyaratkan komisaris independen berjumlah minimal 0,30 dari Dewan Komisaris.

Struktur kepemilikan (institusional dan manajerial) merupakan mekanisme corporate governance yang mampu menurunkan konflik antara shareholders dengan pengurus perusahaan guna meningkatkan kinerja keuangan perusahaan. Kepemilikan institusional merupakan perbandingan jumlah saham investor institusi dengan jumlah saham beredar dalam sebuah perusahaan (Chung \& Zhang, 2011). Kepemilikan manajerial merupakan perbandingan bagian saham pengurus perusahaan (komisaris, direktur, dan manajemen) dengan jumlah saham beredar (Wahidahwati, 2002). Family Duality adalah kondisi terdapatnya seseorang atau keluarganya menduduki jabatan sebagai CEO sekaligus sebagai chairman of board sehingga dapat meningkatkan terjadinya pemusatan kekuatan dan mengakibatkan adanya potensi pengambilan keputusan yang bebas (Murhadi, 2009).

Hedging adalah tindakan untuk menghindari atau meminimalkan risiko kerugian dalam konversi atau transaksi devisa, dalam hal investasi dan pembayaran tagihan dan lainnya dengan mata uang yang berbeda (Kasidi, 2014). Aktivitas hedging dilakukan melalui instrumen derivatif yang terdiri dari kontrak forward, futures, swaps, dan options (Madura, 2009).

Profitabilitas merupakan tingkat efisiensi dan efektivitas pengurus dalam mengolah harta perusahaan. Rasio profitabilitas memberikan gambaran kemampuan perusahaan dalam memberikan laba dari pengelolaan aktiva perusahaan (Jannati et al., 2014). Leverage merupakan rasio yang memberikan gambaran kemampuan perusahaan dalam melunasi kewajiban jangka pendek dan jangka Panjang (Wiagustini, 2013). Jika rasio leverage perusahaan semakin tinggi berarti dalam pembiayaan modalnya perusahaan menggunakan lebih banyak utang daripada modal sendiri dimana hal ini dapat menyebabkan perusahaan akan atau sedang dalam dalam menghadapi risiko financial distress.

Hipotesis ke-1 sampai dengan ke-4 dalam penelitian ini adalah dewan komisaris, komisaris independen, kepemilikan institusional, dan kepemilikan manajerial berpengaruh positif terhadap keputusan hedging sebelum dan selama pandemi Covid19. Hipotesis ke-5 adalah family duality berpengaruh negatif terhadap keputusan hedging sebelum dan selama pandemi Covid19. Hipotesis ke-6 adalah ada perbedaan mekanisme corporate governance yang paling berpengaruh signifikan terhadap keputusan hedging antara sebelum dan selama pandemi Covid-19.

\section{METODE PENELITIAN}

Penelitian ini adalah penelitian kuantitatif menggunakan Laporan Keuangan audited dan Laporan Tahunan sebagai data sekunder. Dalam penelitian ini variabel yang digunakan terdiri dari variabel terikat yaitu keputusan hedging (Y) dan mekanisme 
corporate governance sebagai variabel bebas dengan menggunakan proksi Dewan Komisaris, Komisaris Independen, kepemilikan institusional, kepemilikan manajerial dan family duality serta variabel kontrol yaitu profitabilitas dan leverage.

Keputusan hedging (HD) didapat dari Laporan Keuangan audited pada Catatan Atas Laporan Keuangan bagian Instrumen Keuangan Derivatif. Keputusan hedging diukur dengan menggunakan variabel dummy dengan ketentuan sebagai berikut:

$\mathrm{HD}=1$, jika perusahaan mengambil keputusan hedging.

$\mathrm{HD}=0$, jika perusahaan tidak mengambil keputusan hedging.

Dewan Komisaris mengawasi kinerja Direksi dalam mengelola perusahaan termasuk pelaksanaan good corporate governance untuk mendapatkan pelepasan tanggung jawab dari RUPS (Rapat Umum Pemegang Saham). Dewan Komisaris termasuk juga Komisaris independen mempunyai fungsi yang mencakup dua hal yaitu pertama, mengawasi kebijakan dan kegiatan yang dijalankan Direksi perusahaan dalam melakukan pengelolaan asset perusahaan secara efektif, efisien, dan ekonomis dengan menerapkan prinsip good corporate governance untuk mencapai performa dalam perencanaan bisnis perusahaan dan fungsi yang kedua apabila ada penyimpangan dalam mengelola usaha terhadap tujuan perusahaan maka dapat memberikan pendapat atau arahan kepada Direksi (Sutedi, 2015). Pelaksanaan corporate governance yang baik perlu dijamin dengan integritas yang tinggi dan tindakan profesional dari anggota Dewan
Komisaris, dimana tidak memihak kepada salah satu pemegang saham pengendali. Dewan Komisaris dapat diukur dengan rumus, sebagai berikut:

$\mathrm{DK}_{\text {it }}=\operatorname{Ln}(\Sigma$ Dewan Komisaris it $)$

Jumlah Dewan Komisaris tercantum di Laporan Keuangan Tahunan pada profil Dewan Komisaris dan Laporan Keuangan audited pada Catatan Atas Laporan Keuangan bagian informasi umum.

Komisaris independen tercantum di Laporan Keuangan Tahunan pada profil Dewan Komisaris dan Laporan Keuangan audited pada Catatan Atas Laporan Keuangan bagian informasi umum. Komisaris independen adalah komisaris yang bebas dari hubungan apapun terkait pengelolaan perusahaan (Kyere \& Ausloos, 2021). Pengangkatan komisaris independen bertujuan melindungi kepentingan para pemegang saham. Komisaris independen dapat diukur dengan rumus, sebagai berikut:

Komind it $=\frac{\text { Komisaris Independen it }}{\sum \text { Dewan Komisaris it }}$

Kepemilikan institusional didapat dari Laporan Tahunan perusahaan pada bagian informasi pemegang saham (profil perusahaan). Kepemilikan institusional adalah proporsi jumlah saham perusahaan yang dimiliki oleh investor institusi (Chung \& Zhang, 2011). Investor institusi lebih menyukai perusahaan yang memiliki mekanisme corporate governance yang baik. Institusi tersebut dapat berupa institusi pemerintah, swasta domestik maupun asing. Kepemilikan institusional dapat diukur dengan rumus, sebagai berikut: 
INSOWN $_{\mathrm{it}}=\frac{\sum \text { sahaminstitusionalit }_{\mathrm{t}}}{\sum \text { saham beredarit }_{\mathrm{t}}} \times 100 \%$

Kepemilikan manajerial didapat dari Laporan Tahunan perusahaan pada bagian informasi pemegang saham (profil perusahaan).Menurut Agustia et al., (2018) kepemilikan manajerial adalah perbandingan jumlah saham milik manajemen (Direksi dan Komisaris) yang dihitung dengan rumus sebagai berikut:

MANSOWN $_{\mathrm{it}}=\frac{\sum \text { saham manajerialit }_{\text {it }}}{\sum \text { saham beredarit }} \times 100 \%$

Family duality tercantum di Laporan Tahunan pada profil Dewan Komisaris dan profil Dewan Direksi serta Laporan Keuangan audited pada Catatan Atas Laporan Keuangan bagian informasi umum. Family Duality adalah hubungan kekerabatan antara Dewan Komisaris dan Dewan Direksi. Berdasarkan penelitian Kouki et al., (2011) untuk variabel Dual digunakan variabel dummy dengan ketentuan sebagai berikut:

DUAL $=1$, jika terdapat hubungan kekerabatan antara Komisaris dan Direksi.

DUAL $=0$, jika tidak terdapat hubungan kekerabatan antara Komisaris dan Direksi.

Profitabilitas diberikan simbol PROF dan diukur dengan menggunakan Return on Asset (ROA), dengan rumus sebagai berikut: $\mathrm{ROA}_{\text {it }}=\frac{\text { Laba bersih setelah pajak it }}{\text { Total Aktiva it }} \times 100 \%$

Leverage diberikan simbol LEV dan diukur dengan menggunakan Debt to Equity ratio, dengan rumus sebagai berikut:

DER $_{\text {it }}=\frac{\text { Total hutang }_{\text {it }}}{\text { Total ekuitas it }}$

Penelitian ini menggunakan populasi perusahaan manufaktur di Bursa Efek
Indonesia periode tahun 2019-2020. Metode purposive sampling digunakan dalam pengambilan sampel. Kriteria penentuan sampel adalah perusahaan manufaktur yang terdaftar di Bursa Efek Indonesia pada periode tahun 2019-2020, kecuali untuk perusahaan yang dikategorikan manufaktur namun tidak menjalankan kegiatan manufaktur, dan perusahaan yang kelengkapan data Laporan Keuangan dan Laporan Tahunan periode tahun 2019-2020 masih kurang sehingga diperoleh 366 perusahaan sampel.

Pengumpulan data menggunakan metode pengumpulan data sekunder. Data sekunder dikumpulkan melalui Laporan Keuangan audited dan Laporan Tahunan yang diterbitkan perusahaan dan disetorkan ke Bursa Efek Indonesia tahun 2019-2020.

Model analisis merujuk pada penelitian yang dilakukan oleh Muiru et al., (2019); Bhagawan \& Lukose (2017). Dari hasil kajian teori mengidentifikasi bahwa Dewan komisaris, Komisaris independen, kepemilikan institusional, kepemilikan manajerial, family duality, profitabilitas dan leverage mempengaruhi keputusan hedging.

Hipotesis diuji dengan teknik analisis observasi yaitu melakukan Analisa Laporan Keuangan audited dan Laporan Tahunan yang diperoleh dan menetapkan hasil sesuai data yang ada dengan 2 tahapan. Pada tahap pertama, sampel perusahaan akan dikelompokkan menjadi 2 yaitu perusahaan yang mengambil keputusan hedging (diberi kode 1) dan perusahaaan yang tidak mengambil keputusan hedging (diberi kode $0)$. 


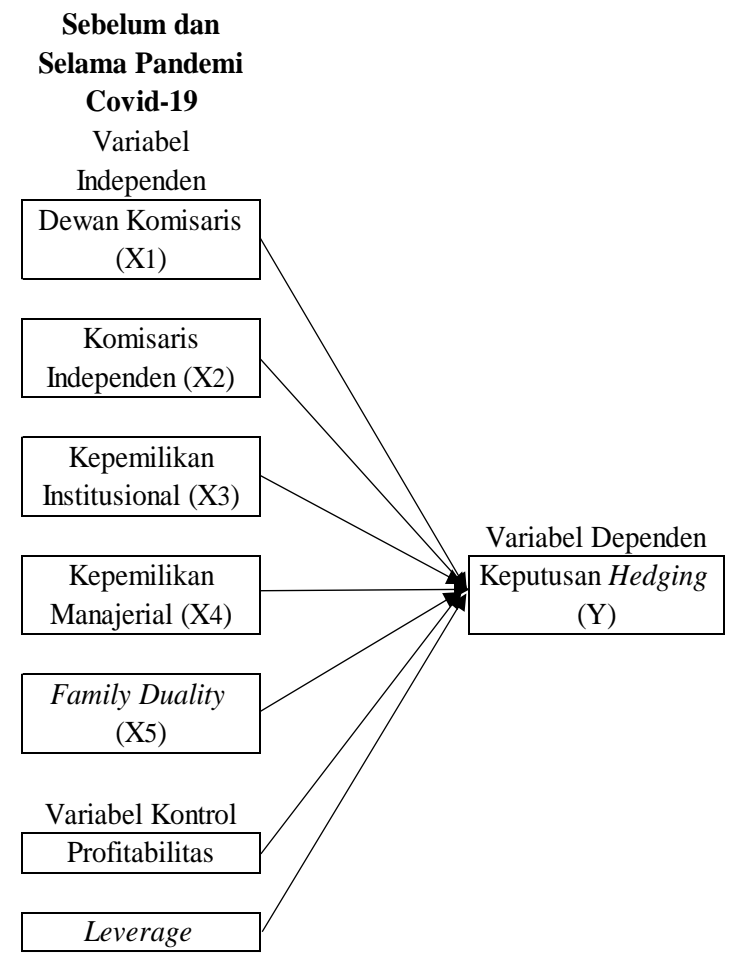

Gambar. 1

Model Analsis Penelitian

Untuk masing-masing sampel perusahaan dihitung dewan komisaris, komisaris independen, kepemilikan institusional, kepemilikan manajerial, family duality dengan memberikan kode 1 untuk yang terdapat hubungan kekerabatan antara Komisaris dan Direksi dan kode 0 untuk yang tidak terdapat hubungan kekerabatan antara Komisaris dan Direksi, profitabilitas dan leverage.

Setelah didapat data masing-masing variabel dari setiap perusahaan sampel, maka pada tahap kedua akan dilakukan pengujian statistik untuk mengetahui hubungan antar variabel bebas terhadap variabel terikat dengan menambahkan dummy untuk membedakan data periode sebelum pandemi Covid-19 diberikan kode 0 dan selama pandemi Covid-19 diberikan kode 1.
Pengujian hubungan antar variabel dilakukan dengan analisis regresi logistik untuk data perusahaan tahun 2020 dan tahun 2019. Analisis regresi logistik adalah suatu metode analisis statistik mendeskrispsikan hubungan antar peubah respon yang memiliki 2 kategori atau lebih dengan 1 atau lebih peubah bebas berskala kategori atau interval (Hosmer, 2000). Alasan penggunaan analisis regresi logistik adalah karena variabel DUAL dan HD merupakan data berskala kategori. Sedangkan alat uji yang digunakan untuk menganalisis penelitian ini adalah program SPSS 23.

Uji regresi data yang berasal dari periode yang berbeda dapat digabungkan dengan menambah variabel dummy (D) sehingga analisa data yang berasal dari periode yang berbeda dapat dilakukan dalam satu persamaan regresi berganda (Gujarati, 2003). Variabel dummy akan dikalikan dengan masing-masing variabel bebas sehingga memungkinkan peneliti untuk membedakan koefisien antar periode. Jika hasil analisa statistik koefisien dummy berpengaruh signifikan maka persamaan yang terbentuk adalah sebagai berikut:

Untuk $\mathrm{D}=0, \mathrm{Y}=\alpha+\beta \mathrm{X}$

Untuk $\mathrm{D}=1, \mathrm{Y}=\alpha+\left(\beta_{1}+\beta_{2}\right) \mathrm{X}$

Periode analisa adalah sebelum dan selama pandemi Covid-19. Untuk data periode sebelum pandemi Covid-19 diberikan kode 0 dan untuk periode selama pandemi Covid-19 diberikan kode 1.

Tujuan dari pengujian ini adalah untuk mengetahui ada/tidaknya perbedaan pengaruh signifikan antar variabel DK, KOMIND, INSOWN, MANOWN, DUAL, PROF, dan LEV terhadap keputusan hedging 
Corporate Governance Dalam Keputusan... Andy Yesaya Tjandra \& Andry Irwanto

sebelum dan selama pandemi Covid-19. Hasil pengujian analisis regresi logistik akan menghasilkan suatu hasil perhitungan untuk menerima atau menolak hipotesis $\mathrm{H} 1, \mathrm{H} 2$, H3, H4, H5 dan H6. Rumusan model persamaan regresi logistik adalah sebagai berikut:

$\mathrm{HD}_{\mathrm{it}}=\alpha+\beta_{0} \mathrm{D}+\beta_{1} \mathrm{DK}_{\mathrm{it}}+\beta_{2} \mathrm{DK}_{\mathrm{it}} \mathrm{D}+$
$\beta_{3}$ KOMIND $_{\mathrm{it}}+\beta_{4} \mathrm{KOMIND}_{\mathrm{it}} \mathrm{D}+$
$\beta_{5} \mathrm{INSOWN}_{\mathrm{it}}+\beta_{6} \mathrm{INSOWN}_{\mathrm{it}} \mathrm{D}+$
$\beta_{7} \mathrm{MANOWN}_{\mathrm{it}}+\beta_{8} \mathrm{MANOWN}_{\mathrm{it}} \mathrm{D}+$
$\beta_{9}$ DUAL $_{\mathrm{it}}+\beta_{10}$ DUAL $_{\mathrm{it}} \mathrm{D}+\beta_{11} \mathrm{PROF}_{\mathrm{it}}+$
$\beta_{12}$ PROF $_{\mathrm{it}} \mathrm{D}+\beta_{13} \mathrm{LEV}_{\mathrm{it}}+\beta_{14} \mathrm{LEV}_{\mathrm{it}} \mathrm{D}+\mathrm{e}_{\mathrm{it}} \ldots$ (9)

Keterangan:

\begin{tabular}{|c|c|}
\hline $\mathrm{HD}_{\text {it }}$ & $\begin{array}{l}\text { Keputusan Hedging untuk } \\
\text { perusahaan i pada tahun } \mathrm{t}\end{array}$ \\
\hline$\alpha$ & konstanta \\
\hline$\beta$ & : koefisien model regresi \\
\hline D & Dummy \\
\hline $\mathrm{DK}_{\mathrm{it}}$ & $\begin{array}{l}\text { Dewan Komisaris untuk } \\
\text { perusahaan i pada tahun } \mathrm{t}\end{array}$ \\
\hline KOMIND it $_{\text {it }}$ & $\begin{array}{l}\text { Komisaris Independen untuk } \\
\text { perusahaan i pada tahun } \mathrm{t}\end{array}$ \\
\hline $\mathrm{INSOWN}_{\text {it }}$ & $\begin{array}{l}\text { Kepemilikan Institusional } \\
\text { untuk perusahaan i pada } \\
\text { tahun } \mathrm{t}\end{array}$ \\
\hline MANOWN $_{\text {it }}$ & $\begin{array}{l}\text { Kepemilikan Manajerial } \\
\text { untuk perusahaan i pada } \\
\text { tahun } \mathrm{t}\end{array}$ \\
\hline DUAL $_{\text {it }}$ & $\begin{array}{l}\text { Family Duality untuk } \\
\text { perusahaan i pada tahun } \mathrm{t}\end{array}$ \\
\hline $\mathrm{PROF}_{\text {it }}$ & $\begin{array}{l}\text { Profitabilitas untuk } \\
\text { perusahaan i pada tahun } \mathrm{t}\end{array}$ \\
\hline $\mathrm{LEV}_{\text {it }}$ & $\begin{array}{l}\text { Leverage untuk perusahaan } \mathrm{i} \\
\text { pada tahun } \mathrm{t}\end{array}$ \\
\hline & koefisien error \\
\hline
\end{tabular}

Kriteria pengambilan keputusan untuk menerima atau menolak hipotesis didasarkan pada tingkat signifikansi 5\%, dimana variabel akan disebut berpengaruh signifikan jika tingkat signifikansinya $<5 \%\left(\mathrm{H}_{0}\right.$ diterima).

\section{HASIL DAN PEMBAHASAN}

Analisis statistik deskriptif digunakan untuk menerangkan variabel dalam penelitian. Variabel yang digunakan meliputi hedging sebagai variabel dependen, mekanisme corporate governance sebagai variabel independen serta profitablitas dan leverage sebagai variabel kontrol. Data penelitian sebanyak 366 perusahaan manufaktur yang terdaftar di Bursa Efek Indonesia periode 2019-2020 dan hasil pengolahan data dalam penelitian ini pada Tabel 1 .

Tabel 1. Statistik Deskriptif

\begin{tabular}{lccccc}
\hline & $\mathrm{N}$ & Min & Max & Mean & $\begin{array}{c}\text { Std. } \\
\text { Deviation }\end{array}$ \\
\hline DK & 366 & 2 & 10 & 3,86 & 1,692 \\
KOMIND & 366 &, 0000 & 1,0000 &, 413606 &, 1087466 \\
INSOWN & 366 &, 0000 &, 9995 &, 666575 &, 2730481 \\
MANOWN & 366 &, 0000 &, 8944 &, 083475 &, 1799923 \\
DUAL & 366 & 0 & 1 &, 24 &, 430 \\
PROF & 366 & $-1,0498$ &, 9416 &, 029074 &, 1264745 \\
LEV & 366 & $-19,0556$ & 114,289 & 1,54074 & 6,5775182 \\
& & & 6 & 5 & \\
Valid N & 366 & & & & \\
(listwise) & 366 & & & & \\
\hline
\end{tabular}

Sumber: data olahan SPSS 23, 2022

Hasil pengujian kesesuaian model dengan nilai observasi menggunakan Hosmer and Lemeshow test pada Tabel 2.

Tabel 2.

Hosmer and Lemeshow Test

\begin{tabular}{lll}
\hline Chi-square & df & Sig. \\
\hline 12,295 & 8 &, 139 \\
\hline
\end{tabular}

Sumber: data olahan SPSS 23, 2022

Nilai Chi Square Hosmer and Lemeshow hitung sebesar 12,295 < nilai Chi Square Tabel (untuk DF 8 pada taraf signifikansi 0,05) yaitu sebesar 15,507.

Tingkat signifikansi sebesar 0,139 (> 0,05). Hal ini menunjukkan bahwa model 
dapat diterima dan pengujian hipotesis dapat dilakukan sebab tidak ada perbedaan signifikan antara model dengan nilai observasinya.

Hasil pengujian ketepatan model penelitian pada Tabel 3. Berdasarkan Tabel 3, ketepatan model penelitian ini adalah sebesar $88,3 \%$.

Tabel 3. Classification Table

\begin{tabular}{ccccc}
\hline \multirow{2}{*}{ Observed } & \multicolumn{3}{c}{ Predicted } & \\
\cline { 3 - 4 } & & \multicolumn{2}{c}{ HD } & \\
\cline { 3 - 4 } tep 1 D & \multicolumn{2}{c}{ TIDAK } & & \\
& & HEDGING HEDGING & \% & Correct \\
\hline & HEDGING & 317 & 1 & 99,7 \\
\cline { 2 - 4 } & HEDGING & 42 & 6 & 12,5 \\
\cline { 2 - 4 } $\begin{array}{c}\text { Overall } \\
\text { Percentage }\end{array}$ & & & 88,3 \\
\hline
\end{tabular}

Sumber: data olahan SPSS 23, 2022

Hasil uji pengaruh simultan variabel independen terhadap variabel dependen pada Tabel 4.

Tabel 4.

Model Summary

\begin{tabular}{lccc}
\hline & \multicolumn{3}{c}{ Cox \& Snell R Nagelkerke R } \\
S step & -2Log likelihood & Square & Square \\
\hline 1 & 251,583 &, 086 &, 159
\end{tabular}

Sumber: data olahan SPSS 23, 2022

Berdasarkan Tabel 4, nilai Nagelkerke R Square sebesar 0,159 dan Cox \& Snell R Square 0,086, berarti bahwa kemampuan variabel independen dalam menjelaskan variabel dependen adalah sebesar 0,159 atau $15,9 \%$ dan terdapat $84,1 \%$ faktor lain di luar model yang menjelaskan variabel dependen yang tidak masuk sebagai variabel dependen dalam penelitian ini.
Tabel 5.

Tabel Hasil Uji Regresi

\begin{tabular}{lrr}
\hline & $\beta$ & Sig. \\
\hline DK &, 362 &, 003 \\
\hline KOMIND & 1,187 &, 537 \\
\hline INSOWN &,- 827 &, 465 \\
\hline MANOWN & $-2,261$ &, 313 \\
\hline DUAL &,- 125 &, 827 \\
\hline PROF & 1,688 &, 312 \\
\hline LEV &,- 007 &, 931 \\
\hline DUMMY & $-1,309$ &, 520 \\
\hline DK_D &, 155 &, 397 \\
\hline KOMIND_D &, 607 &, 837 \\
\hline INSOWN_D &, 261 &, 876 \\
\hline MANOWN_D & 1,940 &, 531 \\
\hline DUAL_D &, 207 &, 811 \\
\hline PROF_D &,- 232 &, 930 \\
\hline LEV_D &,- 009 &, 936 \\
\hline Constant & $-3,221$ &, 017 \\
\hline
\end{tabular}

Sumber: data olahan SPSS 23, 2022

Berdasarkan Tabel 5, hasil uji regresi logistik pada SPSS 23 adalah variabel independen DK berpengaruh signifikan terhadap pengambilan keputusan hedging sebagai variabel dependen. Variabel independen DK, KOMIND, PROF memiliki nilai $\beta$ yang bernilai positif. Hal ini berarti variabel independen memiliki hubungan yang searah dengan pengambilan keputusan hedging sebagai variabel dependen. Variabel independen INSOWN, MANOWN, DUAL, LEV, DUMMY memiliki nilai $\beta$ yang bernilai negatif. Hal ini berarti variabel independen memiliki hubungan yang berlawanan arah dengan pengambilan keputusan hedging sebagai variabel dependen. Variabel dummy tidak memiliki pengaruh yang signifikan karena nilai signifikansi 0,520 yang lebih besar dari $\alpha$ $(0,05)$ sehingga tidak terdapat perbedaan faktor yang mempengaruhi pengambilan 
keputusan hedging untuk tahun 2019 dan tahun 2020.

Berdasarkan Tabel 5 hasil uji regresi menunjukkan bahwa variabel independen dummy tidak memiliki pengaruh yang signifikan karena nilai signifikansi 0,520 $(>0,05)$ sehingga tidak terdapat perbedaan mekanisme corporate governance yang paling berpengaruh signifikan terhadap keputusan hedging antara tahun 2019 dan tahun 2020. Oleh karena itu dilakukan pengujian ulang statistik regresi logistik data 2019-2020 (Tabel 6) dan dihasilkan persamaan sebagai berikut:

$\operatorname{Ln} \frac{\mathrm{p}}{1-\mathrm{p}}=-3,275+0,422 \mathrm{DK}+1,459 \mathrm{KOMIND}$

$-0,735$ INSOWN-1,786MANOWN

$-0,153 \mathrm{DUAL}+1,611 \mathrm{PROF}-0,014 \mathrm{LEV}$.

Tabel 6.

Tabel Hasil Uji Regresi data tahun 2019-2020

\begin{tabular}{lrr}
\hline & $\beta$ & Sig. \\
\hline DK &, 422 &, 000 \\
\hline KOMIND & 1,459 &, 317 \\
\hline INSOWN &,- 735 &, 377 \\
\hline MANOWN & $-1,786$ &, 268 \\
\hline DUAL &,- 153 &, 725 \\
\hline PROF & 1,611 &, 212 \\
\hline LEV &,- 014 &, 793 \\
\hline Constant & $-3,725$ &, 000 \\
\hline
\end{tabular}

Sumber: data olahan SPSS 23, 2022

Berdasarkan Tabel 6, hasil pengujian regresi logistik pada SPSS 23 menunjukkan bahwa variabel independen DK berpengaruh signifikan terhadap pengambilan keputusan hedging. variabel independen DK, KOMIND, dan PROF memiliki $\beta$ yang bernilai positif yang berarti memiliki hubungan searah dengan variabel dependen keputusan hedging. Variabel independen INSOWN, MANOWN,
DUAL dan LEV memiliki nilai $\beta$ yang bernilai negatif yang berarti memiliki hubungan tidak searah dengan variabel dependen keputusan hedging.

Berdasarkan hasil penelitian yang disajikan pada Tabel 6, nilai koefisien $\beta$ untuk variabel independen Dewan Komisaris sebesar 0,422 dan tingkat signifikansi 0,000 $(<0,05)$ yang berarti variabel DK berpengaruh positif secara signifikan terhadap keputusan hedging sebelum dan selama pandemi Covid19 sehingga menerima hipotesis yang menyatakan bahwa Dewan Komisaris berpengaruh positif terhadap keputusan hedging sebelum dan selama pandemi Covid19. Hal ini didukung dengan penelitian Kyere \& Ausloos (2021) yang menyatakan Dewan Komisaris berpengaruh terhadap kinerja keuangan dimana pada penelitian Muiru et al., (2019) menyatakan corporate governance dapat memoderasi hubungan antara hedging dan kinerja keuangan. Hal ini sesuai dengan tujuan UU PT No 40 Tahun 2007 ayat 6 dimana Dewan Komisaris sebagai pengawas dan penasehat Dewan Direksi dalam mengambil keputusan operasional perusahaan.

Nilai koefisien $\beta$ untuk variabel independen Komisaris Independen sebesar 1,459 dan tingkat signifikansi 0,317 (>0,05). Hal ini berarti komisaris independen berpengaruh positif tidak signifikan terhadap keputusan hedging sebelum dan selama pandemi Covid-19 sehingga menolak hipotesis yang menyatakan bahwa Komisaris Independen berpengaruh positif terhadap keputusan hedging sebelum dan selama pandemi Covid-19. Hasil koefisien $\beta$ yang positif menunjukkan hubungan yang searah 
antara Komisaris Independen dengan keputusan hedging dimana menunjukkan semakin banyak jumlah Komisaris Independen maka semakin mempengaruhi pengambilan keputusan hedging. Namun tingkat signifikansinya menyatakan tidak signifikan sehingga Komisaris Independen tidak mempengaruhi keputusan hedging dimana tidak sejalan dengan penelitian Kyere \& Ausloos (2021) yang menyatakan Komisaris Independen berpengaruh terhadap kinerja keuangan dimana pada penelitian Muiru et al., (2019) menyatakan corporate governance dapat memoderasi hubungan antara hedging dan kinerja keuangan. Hal ini dapat disebabkan oleh adanya Komisaris Independen hanya untuk memenuhi peraturan yang berlaku saja sehingga peran Komisaris Independen dalam perusahaan masih kurang.

Nilai koefisien $\beta$ untuk variabel independen kepemilikan institusional sebesar $-0,735$ dan tingkat signifikansi $0,377(>0,05)$. Hal ini berarti kepemilikan institusional berpengaruh negatif tidak signifikan terhadap keputusan hedging sebelum dan selama pandemi Covid-19 sehingga menolak hipotesis yang menyatakan bahwa kepemilikan institusional berpengaruh positif terhadap keputusan hedging sebelum dan selama pandemi Covid-19. Hasil penelitian ini tidak sejalan dengan penelitian Muiru et al., (2019) yang menyatakan ownership structure dapat memperkuat atau melemahkan aktivitas teknik hedging. Hal ini disebabkan adanya fenomena pemilik saham perusahaan yang memiliki perusahaan sampel merupakan Dewan Direksi dan Dewan Komisaris dari perusahaan sampel sebagai contoh PT Morenzo Abadi Perkasa Tbk
(ENZO) dimiliki oleh PT Tritunggal Sukses Investama dimana pemiliknya adalah Tuan Markus Silitonga selaku Direktur Utama dari PT Morenzo Abadi Perkasa Tbk.

Nilai koefisien $\beta$ untuk variabel independen kepemilikan manajerial sebesar 1,786 dan tingkat signifikansi $0,268(>0,05)$. Hal ini berarti kepemilikan manajerial berpengaruh negatif tidak signifikan terhadap keputusan hedging sebelum dan selama pandemi Covid-19 sehingga menolak hipotesis yang menyatakan bahwa kepemilikan manajerial berpengaruh positif terhadap keputusan hedging sebelum dan selama pandemi Covid-19. Hasil penelitian ini tidak sejalan dengan penelitian Muiru et al., (2019) yang menyatakan ownership structure dapat memperkuat atau melemahkan aktivitas teknik hedging. Dan tidak sesuai dengan aliran studi yang berpendapat bahwa kepemilikan manajerial yang lebih tinggi akan menurunkan biaya agensi dan menghasilkan kinerja atau nilai perusahaan yang lebih baik (Shan, 2019). Hal ini disebabkan karena rata-rata tingkat kepemilikan manjerial perusahaan sampel hanya sebesar 8,34 persen (Tabel 1).

Nilai koefisien $\beta$ untuk variabel independen family duality sebesar - 0,153 dan tingkat signifikansi $0,725(>0,05)$. Hal ini berarti family duality berpengaruh negatif tidak signifikan terhadap keputusan hedging sebelum dan selama pandemi Covid-19 sehingga menolak hipotesis yang menyatakan bahwa family duality berpengaruh negatif terhadap keputusan hedging sebelum dan selama pandemi Covid-19. Hasil penelitian ini tidak sejalan dengan penelitian Muiru et al., (2019) yang menyatakan CEO Duality 
dapat memperkuat atau melemahkan aktivitas teknik hedging. Pengaruh negatif berarti peningkatan hubungan kekerabatan dalam perusahaan akan menyebabkan penurunan dalam pengambilan keputusan hedging (Tabel 7) dimana menunjukkan semakin kecil hubungan kekerabatan maka semakin tinggi pengambilan keputusan hedging.

Tabel 7.

Perbandingan Perusahaan Family Duality dengan Keputusan Hedging 2020

\begin{tabular}{|c|c|c|c|c|}
\hline & \multicolumn{2}{|c|}{ Hedging } & \multicolumn{2}{|c|}{ Tidak Hedging } \\
\hline & Jumlah & $\%$ & Jumlah & $\%$ \\
\hline $\begin{array}{l}\text { Ada } \\
\text { DUAL }\end{array}$ & 4 & $9,30 \%$ & 39 & $90,70 \%$ \\
\hline $\begin{array}{l}\text { Tidak } \\
\text { ada } \\
\text { DUAL }\end{array}$ & 19 & $13,57 \%$ & 121 & $86,43 \%$ \\
\hline Total & 23 & $12,57 \%$ & 160 & $87,43 \%$ \\
\hline & $\mathrm{He}$ & ging & Tidak & Hedging \\
\hline & Jumlah & $\%$ & Jumlah & $\%$ \\
\hline $\begin{array}{l}\text { Ada } \\
\text { DUAL }\end{array}$ & 5 & $10,87 \%$ & 41 & $89,13 \%$ \\
\hline $\begin{array}{l}\text { Tidak } \\
\text { ada } \\
\text { DUAL }\end{array}$ & 20 & $14,60 \%$ & 117 & $85,40 \%$ \\
\hline Total & 25 & $13,66 \%$ & 158 & $86,34 \%$ \\
\hline
\end{tabular}

Sumber: data olahan, 2022

Pada Tabel 5, dummy memiliki nilai signifikansi 0,520 (>0,05) sehingga menolak hipotesis yang menyatakan adanya perbedaan mekanisme corporate governance paling berpengaruh signifikan terhadap keputusan hedging sebelum dan selama pandemi Covid19. Rata-rata ROA perusahaan sampel terjadi penurunan dari tahun 2019 sebesar 4,47\% menjadi sebesar $1,34 \%$ pada tahun 2020 dimana hal ini menunjukkan profitabilitas perusahaan terjadi penurunan akibat pandemi Covid-19, sejalan dengan hasil penelitian Hilman \& Laturette (2021). Perbedaan kinerja perusahaan yang tercermin dari ROA tidak dapat menghasilkan perbedaan pengaruh signifikan mekanisme corporate governance terhadap keputusan hedging antara masa sebelum pandemi Covid-19 (tahun 2019) dengan masa selama pandemi Covid-19 (tahun 2020), dimana hal ini disebabkan dari sampel perusahaan yang diteliti terdapat 48 sampel dari 366 sampel yang mengambil keputusan hedging dan rata-rata perusahaan yang mengambil keputusan hedging pada tahun 2019 juga mengambil keputusan hedging pada tahun 2020.

\section{SIMPULAN DAN SARAN}

Penelitian ini membahas mengenai mekanisme corporate governance berpengaruh terhadap keputusan hedging pada masa sebelum dan selama pandemi Covid-19. Kesimpulan penelitian yaitu Dewan Komisaris berpengaruh positif secara signifikan terhadap keputusan hedging sebelum dan selama pandemi Covid-19. Komisaris Independen berpengaruh positif tidak signifikan terhadap keputusan hedging sebelum dan selama pandemi Covid-19. Kepemilikan institusional, kepemilikan manajerial, dan Family Duality berpengaruh negatif tidak signifikan terhadap keputusan hedging sebelum dan selama pandemi Covid19. Tidak adanya perbedaan mekanisme corporate governance paling berpengaruh signifikan terhadap keputusan hedging sebelum dan selama pandemi Covid-19.

Penelitian ini dapat menjadi masukan bagi akademis bahwa penerapan corporate governance dalam pengambilan keputusan 
Corporate Governance Dalam Keputusan... Andy Yesaya Tjandra \& Andry Irwanto

hedging pada perusahaan publik di Indonesia masih rendah.

Penelitian ini memiliki keterbatasan yang dapat digunakan sebagai dasar penelitian selanjutnya. Data yang digunakan dalam penelitian ini terbatas pada periode tahun 2019-2020 sehingga hasil ini hanya dapat digeneralisasi pada periode tersebut. Keputusan hedging juga dipengaruhi oleh variabel bebas lainnya dimana terlihat pada prosentase ketepatan model dalam penelitian ini. Penelitian selanjutnya diharapkan mampu meneliti faktor-faktor lain yang dapat mempengaruhi keputusan hedging seperti kepemilikan saham mayoritas, komite audit, jenis kelamin dan umur Dewan Komisaris dan Direksi. Selain itu penelitian selanjutnya dapat memperpanjang periode pengamatan agar lebih bisa menjelaskan dan menggambarkan keadaan yang sebenarnya.

\section{REFERENSI}

Agustia, D., Dianawati, W., \& R.A Indah, D. (2018). Managerial Ownership, Corporate Social Responsibility Disclosure and Corporate Performance. Management of Sustainable Development Sibiu, Romania, 10(2), 67-71.

Aslikan, I., \& Rokhmi, S. (2017). Faktor-Faktor Yang Mempengaruhi Keputusan Hedging Pada Perusahaan Manufaktur. Jurnal Ilmu Dan Riset Manajemen, 6(5), 1-21.

Bhagawan, M. P., \& Lukose, P. J. (2017). The Determinants of Currency Derivatives Usage Among Indian Non-Financial Firms: An Empirical Study. Studies in Economics and Finance, 34(3), 363-382. https://doi.org/10.1108/SEF-09-2014-0172

Chung, K. H., \& Zhang, H. (2011). Corporate Governance and Institutional Ownership. Journal of Financial and Quantitative Analysis, 46(1), 247-273. https://doi.org/10.1 017/S0022109010000682

Gujarati, D. N. (2003). Basic econometrics. Fourth
Edition. NewYork: The McGraw Hill Companies.

Hilman, C., \& Laturette, K. (2021). Analisis Perbedaan Kinerja Perusahaan Sebelum Dan Saat Pandemi Covid-19. BALANCE: Jurnal Akuntansi, Auditing Dan Keuangan, 18(1), 91-109. https://doi.org/https:/doi.org/10.251 70/balancev18i1

Hosmer, D. W. \& Lemeshow. S. (2000). Applied Logistic Regression. Second Edition. New York: John Wiley \& Son, Inc.

Jannati, I. D., Saifi, M., \& NP Endang, M. W. (2014). Pengaruh Rasio Leverage Terhadap Profitabilitas (Studi Pada Perusahaan Makanan Dan Minuman Yang Terdaftar di BEI Periode Tahun 2009-2011). Jurnal Administrasi Bisnis (JAB), 8(2), 1-8.

Kaihatu, T. S. (2006). Good Corporate Governance Dan Penerapannya Di Indonesia. Jurnal Manajemen Dan Kewirausahaan, 8(1), 1-9. https://jurnalmanajemen.petra.ac.id/index.php/ man/article/view/16505

Kasidi. (2014). Manajemen Risiko. Cetakan Kedua. Bogor: Penerbit Ghalia Indonesia.

Kementerian PPN/Bappenas. (2020). Laporan Perkembangan Ekonomi Indonesia dan Dunia Triwulan III Tahun 2020. Retrieved from: https://perpustakaan.bappenas.go.id/e-library/ file_upload/koleksi/migrasi-data-publikasi/file /Policy_Paper/Laporan_Perkembangan_Ekon omi_Indonesia_dan_Dunia_Triwulan_III_202 $0 . p d f$

Kouki, M., Elkhaldi, A., Atri, H., \& Souid, S. (2011). Does Corporate Governance Constrain Earnings Management? Evidence from U.S. Firms. European Journal of Economics, Finance and Administrative Sciences, 35, 5871.

Kusmayadi, D., Rudiana, D., \& Badruzaman, J. (2015). Good Corporate Governance. Tasikmalaya: LPPM Universitas Siliwangi.

Kyere, M., \& Ausloos, M. (2021). Corporate Governance and Firms Financial Performance in the United Kingdom. International Journal of Finance and Economics, 26(2), 1871-1885. https://doi.org/10.1002/ijfe.1883

Lel, U. (2012). Currency Hedging and Corporate Governance: A Cross-Country Analysis. Journal of Corporate Finance, 18, 221-237. https://doi.org/10.1016/j.jcorpfin.2011.12.002

Madura, J. (2009). Keuangan Perusahaan Internasional (8th ed.). Jakarta: Salemba Empat. 
Muiru, M. W., Kibet, L. K., \& Kalui, F. (2019). Foreign Exchange Risk Hedging, Corporate Governance and Financial Performance: Evidence From Kenya. Research Journal of Finance and Accounting, 10(5), 88-100. https://doi.org/10.7176/RJFA

Murhadi, W. R. (2009). Studi Pengaruh Good Corporate Governance Terhadap Praktik Earnings Management pada Perusahaan Terdaftar di PT Bursa Efek Indonesia. Jurnal Manajemen Dan Kewirausahaan, 11(1), 110.

Shan, Y. G. (2019). Managerial Ownership, Board Independence and Firm Performance. Accounting Research Journal, 32(2), 203 220. https://doi.org/10.1108/ARJ-09-20170149

Sutedi, A. (2015). Buku Pintar Hukum Perseroan Terbatas. Jakarta: Raih Asa Sukses.

Wahidahwati. (2002). Kepemilikan Manajerial dan Agency Conflicts: Analisis Persamaan Simultan Non Linear dari Kepemilikan Manajerial, Penerimaan Risiko, Kebijakan Utang, Dan Kebijakan Dividen. Prosiding Simposium Nasional Akuntansi V Semarang, 5-6 September, 2002, 601-623.

WHO. (2020). Coronavirus Disease 2019 (COVID-19) World Health Situation Report-1.WHO Indonesia Situation Report. Retrieved from: https://www.who.int/indonesia/news/novelcoronavirus/situation-reports

Wiagustini, N. L. P. (2013). Manajemen Keuangan. Denpasar: Udayana University Press. 